\title{
Renewing the Narrative of the Age to Come: The Kingdom of God in NT Wright and John Zizioulas
}

\author{
Geoffrey Ready
}

check for updates

Citation: Ready, Geoffrey. 2021. Renewing the Narrative of the Age to Come: The Kingdom of God in NT Wright and John Zizioulas. Religions 12: 514. https://doi.org/10.3390/ rel12070514

Academic Editors: Bradley Nassif and Tim Grass

Received: 28 May 2021

Accepted: 2 July 2021

Published: 8 July 2021

Publisher's Note: MDPI stays neutral with regard to jurisdictional claims in published maps and institutional affiliations.

Copyright: (C) 2021 by the author. Licensee MDPI, Basel, Switzerland. This article is an open access article distributed under the terms and conditions of the Creative Commons Attribution (CC BY) license (https:/ / creativecommons.org/licenses/by/ $4.0 /)$.
Orthodox School of Theology at Trinity College, University of Toronto, Toronto, ON M5S 1H8, Canada; geoffrey.ready@utoronto.ca

\begin{abstract}
This paper makes use of leading New Testament scholar NT Wright's presentation of the biblical understanding of the kingdom to assess-on the basis of Orthodox Christian theologian John Zizioulas' own critique-the Orthodox liturgical enactment of the kingdom and age to come. We will explore how Wright and Zizioulas describe the principles of a properly kingdom-oriented worship. Finally, we will examine Wright's critical realism as a potential model for understanding how enacting the age to come in worship could shape the kingdom narrative of its participants. Thus, while Wright's immediate goal in his engagement of the theme of the kingdom of God may be to correct a longstanding misreading of the New Testament, his teaching ultimately enables us to propose a way of accomplishing Zizioulas' hope of renewing the full narrative of the age to come in Orthodox worship.
\end{abstract}

Keywords: Orthodox Christianity; liturgical theology; kingdom of God; narrative; critical realism

\section{Introduction}

One is an evangelical Anglican, among the world's foremost New Testament scholars; the other is Orthodox, the nearest thing in eastern Christianity to a systematic theologian. Yet, both NT Wright and John Zizioulas share common concern about the loss of the eschatological dimension of Christian faith; both express the need to recover the fulness of the kingdom of God in Christian worship and life. Wright's overarching theme is that western Christian tradition has largely forgotten what the gospels are really about, namely, the "devastating and challenging" message of the advent of the kingdom of God and inauguration here and now of the age to come (Wright 2012, p. 37). As Zizioulas explains in many of his works, the same amnesia has impaired the celebration and understanding of Orthodox Christian worship-most particularly, the central act of worship, the Divine Liturgy - and dulled the impact of the devastating and challenging message of the kingdom on Orthodox believers. The Divine Liturgy has lost its power to shock, to announce the revolution consisting of the dethroning and reversal of the world's powers, the victory of God in Jesus, and the kingdom of God already present now in the fulness of the power of self-sacrificing love.

In this paper, we will use Wright's New Testament exegesis and presentation of the biblical understanding of the kingdom to assess — on the basis of Zizioulas' own critique-the Orthodox liturgical enactment of the kingdom and age to come. We will explore how Wright and Zizioulas describe the principles of a properly kingdom-oriented worship. Finally, we will examine Wright's critical realism as a potential model for understanding how enacting the age to come in worship could shape the kingdom narrative of its participants. Thus, while Wright's immediate goal in his engagement of the theme of the kingdom of God may be to correct a longstanding misreading of the New Testament, his teaching ultimately enables us to propose a way of accomplishing Zizioulas' hope of renewing the full narrative of the age to come in Orthodox worship. 


\section{The Kingdom of God in Zizioulas and Wright}

\subsection{The Missing Kingdom Narrative}

Zizioulas follows liturgical theologians such as Alexander Schmemann in describing Orthodox Christian worship as eschatological, concretely symbolising our participation in the life of the age to come: it begins with "the invocation of the Kingdom, continues with the representation of it, and ends with our participation in the Supper of the Kingdom, our union and communion with the life of God in Trinity" (Zizioulas 2011, p. 39). Although it is "glaringly obvious" that the Divine Liturgy is an image of the kingdom of God, John Zizioulas laments the disappearance of the kingdom of God in Orthodox Christian consciousness "under the weight of other kinds of questions and other forms of piety" (ibid., p. 40). He notes that "our theology in recent years does not seem to have given appropriate weight to the eschatological dimension of the Eucharist" (ibid., p. 39)—clarifying elsewhere that by "in recent years" he means everyone since Maximus in the seventh century, and not a few before him! This loss of an eschatological consciousness has had "very grave consequences for the way the Liturgy is celebrated, the piety of the faithful and the whole life of the Church." It is a serious distortion of the Orthodox faith for "we are misled into notions alien to the true Orthodox tradition, often thinking that we are defending Orthodoxy, whereas in fact we are reproducing and promoting ideas foreign to its tradition" (ibid., p. 40).

Throughout his many works of New Testament scholarship, NT Wright echoes the same concern about the profound distortion of Christian faith that results from missing the eschatological dimension of the kingdom of God as a present and coming reality. Like Zizioulas, Wright insists that the full narrative is right in front of our eyes-in the gospels and other writings of the New Testament-but even the sincerest biblically grounded Christians miss it. The main cause of this blindness is an Enlightenment worldview founded on a split-level world similar to ancient Epicureanism: God lives in his heaven, away from human affairs on earth, and the goal of Christian faith becomes salvation conceived as ultimately escaping from this world and going to heaven. The result is a dichotomy between the sacred and secular, a focus on individual piety and salvation, and a reduction of the spiritual life to simply one strand of human existence. Through the lens of this distorted worldview, we miss the essential message of the kingdom of God and the whole of the gospel is reinterpreted. Even the "majestic creeds, full as they are of solemn truth and supple wisdom" prove to be of little use: written to safeguard against specific heresies, without a fuller liturgical and narrative context they do not expound the full story, let alone "the main thing the gospels are trying to tell us," and they even imply the kingdom only comes at the end of time (Wright 2012, p. 16). Echoing the grave consequences Zizioulas observes, Wright notes that this missing kingdom narrative affects everything, including "our discipleship, our preaching, our hermeneutics, and even our praying" (ibid., p. 20).

Wright and Zizioulas are agreed that Christians have strayed away from the eschatology of the early church and inadvertently fallen into a form of gnosticism or Platonism, "substituting 'souls going to heaven' for the promised new creation" (Wright 2016, p. 147). Wright points to the misunderstanding of $\zeta \omega \eta \dot{\eta} \alpha \dot{i} \omega \nu$ เo (literally "life of the age") as an everlasting life understood as "timeless heavenly bliss," rather than as the long-promised age to come in which God would decisively act to bring "justice, peace, and healing to the world as it groaned and toiled within the "present age"' (Wright 2012, pp. 44-45). We need to realise instead that heaven is not our destined place outside of space and time, but it refers rather to "God's space" and earth to "our space" and that heaven and earth, "made from the start to overlap and interlock, did so fully and finally in Jesus" (Wright 2016, p. 162). The kingdom of heaven therefore means God's rule coming to earth—“Thy kingdom come, Thy will be done on earth as it is in heaven" (Matthew 6.10, RSV)—not that good people will go in the future to some kind of disembodied heaven. For Wright, to screen out the inauguration in Jesus of God's kingdom coming on earth as in heaven is not only to adopt a form of gnostic detached spirituality rejected by the early church, but it also 
leads us away from our true image-bearing vocation as humans to "live as worshipping stewards within God's heaven-and-earth reality" (ibid., p. 77).

Where Wright sees a creeping in of ancient errors under modern cultural worldviews unleashed by the Enlightenment, Zizioulas delves directly into the philosophical underpinnings of the missing kingdom narrative. As early as the third century, in authors such as Clement and Origen of Alexandria, Zizioulas sees the development of a Christian gnosticism in which salvation "no longer means the hope of a new world, with a new community and structure" but rather "purifying the soul so that it may be re-united with the Logos who is before all society and before the created and material world" (Zizioulas 2008, p. 129). Christianity is transformed from its purpose of gathering a community "imaging the future kingdom" (ibid., p. 130) into a matter of personal spirituality, of individual piety-the "going to heaven" business, Wright laments. For Zizioulas, this individualistic spirituality, which he admits has sadly dominated since the third century, is theologically and philosophically grounded in a view of causality that looks to what comes before, rather than to the eschaton and "the future recapitulation of human history" (ibid., p. 131). He turns to Maximus for the solution, for in the seventh century confessor he finds a renewed eschatology and emphasis on the future kingdom of God that radically overturns the Greek notion of causality (Zizioulas 2011, p. 42). Zizioulas refers to Maximus' Scholia on Dionysius' Ecclesiastical Hierarchy, in which Maximus follows Dionysius in calling the rites of the

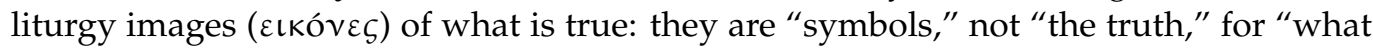
is accomplished visibly" represents "the things that are unseen and secret, which are the causes and archetypes of things perceptible." In other words, the "perceptible symbols" are the effect, whereas the "noetic and spiritual" realities are the causes (ibid., p. 44). Zizioulas points out that at first blush this seems to fit that common reading in Orthodox thought in which the liturgy celebrated on earth is symbolic, imaging forth the true heavenly and eternal liturgy: "one seems to be moving in an atmosphere of Platonism." However, Maximus ends his passage on a surprising note, saying: "For the things of the Old Testament are the shadow; those of the New Testament are the image. The truth is the state of things to come." In this phrase, Zizioulas detects in Maximus a new philosophy of causality and an eschatological ontology in which the eucharistic liturgy and the church are founded neither in a cosmological past nor in a Platonic type of ideal reality, but "in a 'reality of the future', in the Kingdom which is to come" (ibid.). In other words, the "eschaton projects an image of itself backwards" (Zizioulas 2008, p. 137) and what is enacted in the Divine Liturgy is "what is to come, He who comes, and the Kingdom which He will establish" (Zizioulas 2011, p. 45).

For Zizioulas, Maximus' eschatological ontology restores the understanding of the church, constituted by the eucharistic assembly, as the image of the kingdom of God from a dangerously Platonic model to a solidly biblical one. Like Wright, Zizioulas is keen to resist and roll back the Platonising trends in Christian theology to return to a fully biblical eschatology and theology of the age to come. Despite the worrying developments in third century Alexandria and their ongoing distorting effect on Christian faith, for Zizioulas it is Maximus who ensures that the biblical understanding of the kingdom is "securely established on an ontological basis: the Eucharist is not simply connected with the Kingdom which is to come, it draws from it its being and truth" (Zizioulas 2011, p. 45). He therefore frequently laments that Christians approach worship without any eschatological awareness. He especially criticises Orthodox clergy who "dangerously distort" the Divine Liturgy's eschatological character and destroy "the 'image' of the Kingdom that the Liturgy is meant to be," saying that it "would take an entire volume to describe what our Liturgy has suffered at the hands of its clergy" (ibid., p. 46). With that grim warning in mind, we now turn to what Zizioulas and Wright describe as the principles of a properly kingdomoriented worship. 


\subsection{Principles of Kingdom-Oriented Worship}

NT Wright freely admits he is not a liturgist, but as a "New Testament scholar working in a community whose daily life is structured around public and corporate worship" (Wright 2002), he understands the centrality of worship in the kingdom-centred church. Worship, he says, is the "central characteristic of the heavenly life; and that worship is focused on the God we know in and as Jesus" (Wright 1997, p. 5). Understood in light of the kingdom of God, such worship is all-encompassing: the gospel summons us to life "as kingdom-people, reflecting God's image into the world. The way to that goal is worship: worship of the true, sovereign, creator God, Father, Son, and Spirit" (Wright 2002). Wright's vision of the centrality and kingdom-orientation of worship dovetails with the Orthodox Christian vision of liturgy as articulated by Zizioulas. The principles of his kingdom-based theology of worship may therefore complement-and even provide a more pragmatic footing for-the deeply philosophical eschatological liturgical theology of Zizioulas. We will explore here three principles of kingdom-oriented worship outlined by Zizioulas but elaborated by Wright: worship that celebrates the paradoxical climax of the story of Israel, worship that is properly Trinitarian, rejecting all false images of God, and worship that enacts the renewal of the human person, community, and world.

\subsubsection{Worship That Celebrates the Paradoxical Climax of the Whole Narrative of Israel}

Throughout his writings, Wright insists that the work of God in Jesus can only be understood as the climax of the story of Israel. Zizioulas too notes the primary importance of Israel, stating that the nation created from the seed of Abraham "is the source of the Messiah and his eschatological community" and that the church must be understood as the "new Israel" (Zizioulas 2008, p. 126). The church's self-understanding of imaging the kingdom of God in worship arises from the fulfilment of the promises of God and "the expectations of the people of Israel that the scattered people of God would be called together around the Messiah 'on the last day'" (ibid., pp. 127-28). This gathering of the "many into one" becomes one of Zizioulas' most cherished ecclesiological and eschatological themes. It is his central philosophical concept, but it does nevertheless have a certain narrative content: "One of the basic elements of the coming in the last days is the gathering of the scattered people of God-and by extension of all mankind - 'in one place' around the person of the Messiah, in order for the judgement of the world to take place and the Kingdom of God to prevail" (Zizioulas 2011, p. 46). Linking this broad narrative picture directly to the worship of the age to come, he cites the beautiful description of the eucharist "as an image of the eschatological gathering of the scattered children of God" from the liturgy within the Didache (9.4): "Even as this broken bread was scattered over the hills, and was gathered together and became one, so let Thy Church be gathered together from the ends of the earth into Thy Kingdom" (ibid., pp. 46-47). Tellingly, it is precisely the breakdown of this eschatological vision of the gathering of many into one that represents for Zizioulas the alienation of Orthodox worship from the kingdom-oriented liturgy of the early church. In his view, it "survives" (!) in the early second century in Ignatius, and as we have already seen, as late as the seventh century Maximus still calls the Divine Liturgy "synaxis" and image of "the state of things to come," but today the proliferation of eucharistic gatherings points to a distorted image of the "dispersal of the faithful" in stark contrast to the gathering in one place the Divine Liturgy is intended to symbolise (ibid., p. 47).

Where Zizioulas moves quickly from the broad canvas of the story of Israel to a philosophical framework of "many into one," in Wright we have an ongoing appreciation of the full narrative of Israel as the basis of the life of Jesus and subsequently Christian worship in light of the kingdom of God. In liturgy as in the gospels themselves, we have not merely a narrative embroidered with elements of the story of Israel, "detached themes and hints from long ago," but rather the "towering sense of a single story now at last reaching its conclusion" (Wright 2012, p. 72). Jesus' life is told by the evangelists in the context of an "unfinished narrative, an unfinished agenda" in which things were "supposed to happen 
that haven't happened yet" (ibid., p. 66). In the context of the scriptures, the story is badly stalled: there had been "great beginnings and wonderful visions of God's plan and purposes, then a steady decline and puzzling and shameful multiple failures, all ending in a question mark." By the first century, the exile of the people of Israel was not properly over. Some had returned from Babylon, and a second temple had been built in Jerusalem, but they were ruled by pagan foreigners and were slaves in their own land, and the great promises of the prophets had not yet come true (ibid., p. 69). Wright outlines three specific expectations of Israel that would herald the day of the Lord and inauguration of the age to come: Israel would be freed from pagan rule, Israel's God would become "ruler of the world, bringing birth to a new reign of justice and peace," and thirdly, "God's own Presence would come to dwell with this people," enabling them-and with them all the nations of the world - to worship him fully and truly (Wright 2016, p. 160).

The faith and worship of the very earliest Christians grew directly from their conviction that in the death and resurrection of Jesus the Messiah Israel's God himself had arrived at last to renew and restore his people and fulfil this triple hope. Significantly, though, this was not at all as it had been imagined, and a key element of the kingdom in the early church is "that it bursts upon Jesus's first followers as something so shocking as to be incomprehensible" (Wright 2012, p. 197). This paradox lies at the heart of the New Testament: the evangelists and early apostolic writers insist that in Jesus the reality of the kingdom has been made present and Israel's God was already king of the world, though they require their readers to understand Israel's story and hopes in a new way. For Wright, the experience of the disciples on the road to Emmaus (Luke 24,13-35) is paradigmatic of the revelation in true worship of this paradoxical fulfilment of Israel's hope. The disciples, who had been longing for the redemption of Israel by Jesus and whose hopes had been dashed by his death, are led to an event of joyful revelation in the opening of the scriptures and the breaking of bread, that is, in a liturgical event of word and sacrament. Wright points especially to the fact that Christ interprets for the disciples "all the scriptures" (Luke 24,27 ) - in other words, true revelation and worship involves the whole narrative that, "like the risen Jesus himself, is visible to the eye of faith. The story makes sense as a whole or not at all" (ibid., p. 77).

For Wright, the worship of the church must be "soaked" in the whole narrative of Israel as set out in the scriptures so that we "worship in a way which is both sign and means of new creation" (Wright 2017). This worship is "dramatic, performative, setting out and celebrating God's story with the world": the biblical narrative is "a great drama, a great saga, a play written by the living God and staged in his wonderful creation" and in liturgy "we become for a moment not only spectators of this play but also willing participants in it" (Wright 2002). Though, as noted above, he places far less importance on the narrative itself, Zizioulas nevertheless concurs with kingdom-oriented worship being an enacted celebration of God's climactic intervention in history: the story, sacraments and images of liturgy "are created as the Holy Spirit draws us and all our history into relationship with the end time, the reconciliation of all partial kingdoms in the true history of the kingdom of God" (Zizioulas 2008, p. 153). For Zizioulas, this links directly to the anamnesis embodied particularly in the eucharistic liturgy, the remembrance-by participation now in the eschaton - of all time and all kingdoms, of the truth of the world, and "not only of past events, but also of future 'events', i.e., of the Kingdom of God as the culmination of the whole history of salvation" (Zizioulas 2011, p. 41).

\subsubsection{Trinitarian Worship That Rejects Idolatry, Ideology, Dualism and Individualism}

The second principle of kingdom-oriented worship is that it be properly Trinitarian. This principle is famously one of the hallmarks of Zizioulas' theology: it is in the image of the triune God that the church participates now through the eucharist in the gathering of the many into one in the kingdom. Both the church and the eucharist represent communion ( $\operatorname{col} \omega v i \alpha$ ), a Trinitarian way of being; the Trinity is a communion of divine persons that gathers into the kingdom all dispersed human persons and reveals to them a new relational 
way of life, a living for the other (Zizioulas 2010, p. 52). Due to the triune God's desire to have communion with the whole of creation, this living for the other extends also to creation "in its non-human form" (ibid., p. 57). In this way, worship of the true God in Trinity is a turning away, not only from false gods (idolatry) and faiths and worldly powers (ideology), but an overcoming of the dichotomy between spirit and matter (dualism) and the fallen human tendency to live for oneself rather than the other (individualism).

Wright elaborates these same themes in his own exploration of worship within the kingdom of God. His starting point, following the line of thinking in Paul's Epistle to the Romans, is that the essential problem of human existence is not sin, but idolatry: it is "a failure of worship, which leads to, but is itself deeper than, the multiple failures of human living" (Wright 2002). This emerges from the central biblical narrative of the temple, sweeping from creation to the eschaton, wherein God's purpose is to unite heaven and earth and dwell with his people, and the vocation of the image-bearing human being is to freely offer his love, thanksgiving and praise on behalf of all creation. For this worship to be true, however, it must obviously be "the true God you're worshipping" (Wright 1997, p. 7). This was precisely the conflict gripping the entire history of Israel, a struggle of Israel's true God against the pagan deities and tyrants of the world. Over and again, the prophets call Israel to turn from idolatry and return to worship of the true God. Not insignificantly, this clash of the kingdoms-the kingdoms of the tyrants of this world versus the kingdom of the true God to be revealed in the age to come-is especially expounded in the messianic prophecies of Isaiah 40-55 and Daniel, which early Christians saw fulfilled in Jesus.

The distinctively Christian Trinitarian theology of worship emerges directly from Jewish monotheism and its confrontation with idolatry, including pagan polytheism, imperial ideology, and dualism. Worship of the true God is a complete reversal and overthrow of the darkness of idolatry; founded in the death and resurrection of Jesus, it is a "deathblow to the dark forces that had stood in the way of God's new world, God's 'kingdom' of powerful creative and restorative love, arriving 'on earth as in heaven'” (Wright 2012, p. 246). Wright points out the corporate nature of this reversal: all too often in our post-Enlightenment western world we are quick to individualise Christianity and grasp at the personal meaning of repentance and forgiveness, but in doing so we miss the "breathtaking sweep" of the advent of God's kingdom: "Jesus's followers are to go out into the world equipped with the power of his own Spirit to announce that a new reality has come to birth, that its name is 'forgiveness,' and that it is to be had by turning away from idolatry ('repentance')" (Wright 2016, p. 384). At the core of Christian worship is the celebration of this new reality. As Wright says, all those who join in with our worship "ought to be able to sense that living rhythm, that longer vision, that larger horizon of promise" of the fulfilment of God's kingdom (Wright 2017). Even though it will be "complicated, contested, and controversial," we need to continually strive to proclaim in worship and life "the forgiveness of sins and the consequent breaking of the enslaving powers" and the dethroning of all the world's kingdoms (Wright 2016, p. 394). In its place, we do not set another kingdom of the same sort, but we labour for the kingdom "whose power is the power of the servant and whose strength is the strength of love" (Wright 2012, p. 205).

Like Zizioulas, Wright observes that the life of communion of the divine persons of the triune God provides the model for Christian worship. As knowing is defined in relation to its object, "so worship, as a mode of knowing and/or being known, is defined by its object: the God whom we worship." Therefore, the Holy Trinity of Father, Son, and Spirit "is himself in his threefold unity the means and the pattern of our worship" (Wright 2002). United to the Son in an offering of sacrifice and praise to the Father, enabled by the Spirit who calls "forth worship of the Father through the Son," Christians take their place in true kingdom worship that takes place at once in heaven and on earth: in the temple of the body of Christ that unites heaven and earth. Zizioulas notes that the worship around the throne of God and the Lamb depicted in Revelation 4 and 5 corresponds to the "structure of the eucharistic gathering as described to us clearly from the earliest sources" (Zizioulas 2011, p. 17). For Wright as well, the portrayal of heavenly worship in 
Revelation in which we take our place "amongst all the angels and archangels and all the company of heaven" is normative for all worship: and this "is not a vision of the ultimate future-that comes in chapters 21 and 22-but of the heavenly dimension of present reality" (Wright 2002). One of the key functions of kingdom worship is that it enables us to see things as they really are, to grasp within our present sphere the heaven-and-earth unity inaugurated by the death and resurrection of Jesus: it is "in prayer, in scripture study, in the sacraments and in working for God's kingdom in the world" that we "sense fitfully" the heaven-and-earth overlap of the kingdom (Wright 2016, p. 148). This is at heart a Trinitarian action: "Heaven is not a long way away. It is where Jesus and the Spirit are, revealing the Father and drawing us into worship, love, and obedience." Wright explains that in Revelation 4, the expressions used by the apostle, "coming up to heaven" and "being in the Spirit," mean the same thing: "heaven and earth are the interlocking spheres of God's single creation, and when John is 'in the spirit,' he is suddenly open to and aware of the heavenly dimension of what we call ordinary life" (Wright 2002).

\subsubsection{Worship Oriented towards the Renewal and Restoration of All}

Out of this Trinitarian object and shape of worship arises our third principle, that the worship of the one true God in the age to come is oriented towards the renewal of image-bearing human beings in community, for the restoration of the whole world. For Zizioulas, the restored communal life of the kingdom is patterned on the life of the Trinity; by uniting the many into one, the eucharistic community reveals this Trinitarian kingdom, our "ultimate reality" and the "future to us in the form of the present" (Zizioulas 2008, p. 137). To take part in the "community of the end of times," we must become church, because it is "the Church that reflects the transformation of the entire material world and with it all human society and community" (ibid., p. 135). In its eschatological worship, the church reconciles and unites all creation in Christ, and already participates in the uncreated light and glory of God. Though it draws its very existence from the end, however, the church is nevertheless in constant progression towards that end. Zizioulas laments that-in the predominant Platonic view that sees the earthly liturgy as the image of an ideal heavenly liturgy without reference to time- the Divine Liturgy has come to be viewed as static, whereas it should be understood as both the dynamic journey to the kingdom and the proleptic coming of the kingdom (Zizioulas 2011, p. 48). This ongoing progression of the church, he says, lies along a narrow path in which the kingdom is being realised within it. As the life of the age to come already is, it is not a matter for kingdom worship to simply depict this life by way of "parable or allegory"; rather, it is "the symbolism of an icon as that is understood by the Fathers of the Church," meaning that the church participates directly "in the ontological content of the prototype" (ibid., p. 50). The liturgy of the age to come reveals the overcoming of evil and defeat of the devil, and "the future of the world, in which both society and all material creation overcome corruption" (Zizioulas 2008, p. 135). This experience of participating in the end reveals a new way of being in which we live no longer according to the present evil age but, by the power of the Holy Spirit, according to the life of the kingdom to come. This new participative eschatological ontology heals our distorted relations for we know each other, not as we have been, as sinful, self-centred individuals, but as we will be in the glorious life of communion of the age to come, and it therefore leads to new actions and new witness within the world.

Wright mirrors Zizioulas in emphasising the transformative character of worship, though as ever he bases this more deeply in the scriptural narrative of the kingdom and on biblical imagery than systematic theology and ecclesiology. Worship is intended to be the primary means by which God's temple project outlined in Genesis is taken forward. It is worship that makes us human: it is what we were created for, the purpose of our image-bearing, and it is the "truly human stance" (Wright 2002). Jesus Christ himself, in his true humanity, fulfils and renews the image of God and becomes the "source, model, and goal or our own becoming truly human." In Jesus a new mode of being human is established, founded in self-sacrificing love and forgiveness, and it is in worship that this 
new way of being human is acquired, for "we not only become like the God we see in Jesus Christ, but we reflect this God in our own lives and to the people and places where we are placed." Indeed, true worship is the real world, Wright says, echoing Zizioulas; it is the ultimate basis of human reality. It is precisely as we worship the triune God that we make "real what is true of us through baptism and faith, whereby we become living members of the Jesus Christ who in his perfect manhood offers to the Father that love, obedience, and loyalty which is the true human vocation" (ibid.).

For Wright, this true kingdom worship should lead directly to living here and now the signs of that new world. Liturgically, those signs are the sacraments, and above all the eucharist, through which all of creation can become the signposts of God's new heavenand-earth creation, and in which "symbols of the natural world become vehicles of the heavenly world, of which we are called to be citizens" (Wright 1997, p. 11). Alongside the sacraments, though, another of the key signs of the new kingdom is that worship find expression in active political and social engagement, in which we are "urged and encouraged to celebrate the lordship of Jesus Christ over the whole creation, in anticipation of the day when at his name every knee shall bow" (Wright 2002). By contrast, Zizioulas admits that the church's "eschatological dimension has a public outworking," but he is minded that it not involve itself in organised social outreach and its secular administrative systems: avoiding the extremes of "quietism" and political engagement, he argues for "unforced person-to-person charity" reflecting the kingdom's personal encounter and love, which "must always be free" (Zizioulas 2008, p. 127).

\subsection{Renewing the Narrative of the Age to Come}

As we have seen in their description of kingdom-oriented worship, both John Zizioulas and NT Wright emphasise the indispensable role of worship in the experience here and now of the life of the age to come, and they both clearly teach that liturgy shapes people for the kingdom. For Zizioulas, the key to participating in the kingdom is an awareness of eschatological identity, an understanding that true causality is the future not the past, and that the true nature of all people and things is what they will be in the age to come (Zizioulas 2010, p. 15). This knowledge is itself transformative, allowing human beings to fulfil their image-bearing vocation to be kingdom-builders: the "more of your eschatological identity you carry with you, the more you will love and come to the aid of whomever needs your help, whatever it costs you" (Zizioulas 2008, p. 32). Apart from insisting on our iconological participation in the eschaton through the Divine Liturgy, however, Zizioulas never articulates in any practical way how awareness of this eschatological identity is to be acquired, how eschatological ontology works through worship to make us into people who belong in and derive their being from the age to come. A pragmatic solution is sorely needed, though: we have already seen just how scathingly he decries clergy who, lacking the proper eschatological awareness, have turned the liturgy into "a distortion of the image of the last times" (Zizioulas 2011, p. 46).

Throughout this paper, we have seen that, while sharing Zizioulas' concern for the dearth of awareness among Christians of an experience here and now of the new way of life of the age to come, Wright perceives the real solution will come with the recovery the full kingdom narrative. He emphasises that it is in the telling of the story that the work of God in Jesus to establish his kingdom becomes the "mandate and pattern" for the church: "The more you tell the story of Jesus and pray for his Spirit, the more you discover what the church should be doing in the present time" (Wright 2012, p. 119). What Wright says of the gospels could equally be said of the kingdom worship of the Orthodox Divine Liturgy: the story has a "dense and complex centre," and we need to regularly "be struck anew by the thick, rich, multilayered nature" of this narrative, "so full of vivid human scenes, but so evocative in their resonance of meaning about the world, God, life and death, and pretty much everything else" (ibid., p. 157). In the telling of God's story in worship, there is the potential for the transforming encounter and renewal of our minds that we need: 
God has to sweep away all our ideas, including all our ideas about God, in order to draw us, unwilling as we are, face to face with the reality, which is both greater and gentler than we can imagine. And if that is true in our praying and thinking-if it is true that we have to be stripped of our own noisy jumble of thoughts in order to hear afresh the word of the triune God-it is just as true in our living. (Wright 1997, p. 38)

In liturgy, then, God's story shapes our own, the narrative of the age to come moulding us to be citizens and bringers of the kingdom.

The difficulty, of course, is that as Zizioulas and Wright have both identified, it is possible to participate in liturgy or read the gospels and completely miss the clear and overarching narrative of the kingdom that pervades the Christian story. As Wright points out, we have cut the narrative "down to size" and have allowed it "only to speak about the few concerns that happened to occupy our minds already," rather than setting it "free to generate an entire world of meaning in all directions, a new world in which we would discover not only new life, but new vocation." What occupy our minds already are competing narratives that create what Wright calls "bad habits of thought" (Wright 2012, p. 158). These result in perception filters that blind us to even the most obvious elements of God's story, in cognitive biases or subjective perceptions of reality that distort our apprehension of the truths revealed in the narrative and experienced in worship. Wright lays the blame primarily on worldviews arising from a triad of cultural movements over successive centuries - the Enlightenment, Romanticism, and existentialism-that have severely distorted our lenses and prevented us from engaging fully with God's story. As we have already seen, the Enlightenment, "with its ugly ditch between ideas and facts, the eternal truths of reason and the contingent events of history," split religion from real life, divorcing heaven from earth, and subtly pushed the privatisation of faith (Wright 2002). The church swallowed this rhetoric and became content to sell its faith as a means of individuals qualifying for some kind of supratemporal and immaterial heaven after death. Romanticism further distorted the picture by privileging feelings over thoughts and deeds, focusing on the heart, not in the biblical sense as the seat of will and real, personal knowledge, but as the seat of fickle emotions: "it invited you to look within, to see what feelings you had, and to make them the centre of your world, rather than seeing the love of the heart for the true God as the gift of God through gospel, Word, and Spirit." Thirdly, Wright sees the existentialist movements of the 20th century as a blatant return to a form of gnosticism: each of us "has inside ourselves a true self which, though long buried, is now to be discovered and enabled to flourish." This leaves no room for anyone to be confronted, challenged and transformed by the gospel, for it says we need, not redemption, but "to be helped to discover "who you really are'" (ibid.) These cultural lenses have profoundly affected our ability to read and understand God's story, whether written in the scriptures or proclaimed in liturgy. To these distorted lenses, we can also add the imagination-warping dangers of "secular liturgies" such as consumerism. Within our modern life, countless narrative spaces call us to enter in and participate; these stories and spaces form our desires and imaginations, and they alienate us from the kingdom narrative of our true human existence.

In the face of these challenges and competing narratives, it is not adequate simply to declare that liturgy proclaims the new life of the kingdom and forms our "eschatological identity." What we need is a model for the way the liturgy of the kingdom works in practice as a counter-formative influence. We need to understand how participants in kingdom-oriented worship may be converted from the distorted narratives of the present age and begin to apprehend the full divine narrative-how through the words and actions of the liturgy they may begin to imagine and live the way God desires. In NT Wright's comprehensive understanding of the way narrative itself works, the foundation of his own New Testament scholarship, we may discern and adapt just such a model.

In his New Testament studies, Wright sets out a hermeneutical model called "critical realism." Unlike Enlightenment positivism's detached and objective observer, critical 
realism submits that the observer has a distinctive point of view, that the observer interprets through a matrix of expectations, memories, stories, and psychological states, and that the observer's interpretive lenses arise from the communities and contexts belonged to. Rather than working from observations and sensory data to "confident statements about external reality" as in positivism, here realism survives "within the larger framework of the story or worldview which forms the basis of the observer's way of being in relation to the world" (Wright 1993, p. 37). Knowledge takes place "when people find things that fit with the particular story or (or more likely) stories to which they are accustomed to give allegiance." As Wright explains, stories "are one of the most basic modes of human life" (ibid., p. 38). Narratives are not accounts derived from human words and action: rather, what we say and do are "enacted narratives." In other words, "the overall narrative is the more basic category, while the particular moment and person can only be understood within that context." All of our life is based on the overt and hidden narratives that we tell ourselves and one another. Together, they form what critical-realist theoretician Michael Polanyi calls "tacit knowledge," the precognitive filter that enables to sort out what new sensory data and ideas are to be believed. As story-telling humans, we inhabit a story-laden world; our observations, embedded within narratives, are challenged by critical reflection on ourselves as story-tellers, but with new or revised stories we can find "alternative ways of speaking truly about the world" (ibid., p. 44).

This critical-realist framework suggests how kingdom-oriented liturgy may work in practice to shape participants with what should be its "devastating and challenging" narrative. As story-laden creatures, we all come to worship bearing our own complex of explicit and implicit narratives. We are often not aware of them at all, for we have not stopped to perform any narrative criticism on our own lives-we have yet to ponder the plot, the structure, the characters of the stories in which we inhabit. In the readings from the scriptures, the ritual actions and prayers, the liturgy of the kingdom presents us with a myriad of sensory data, ideas and symbols, story-laden events derived from the new life of the age to come. The stories and worldview embedded in the liturgy are meant to subvert all competing stories, for they are in essence revolutionary, proclaiming the dethroning and reversal of all tyrannical powers, the victory of God in Jesus that transforms sorrow into joy, darkness into light, and death into life. As Wright explains, this narrative-shaping role of worship is intentional:

Stories are, actually, peculiarly good at modifying or subverting other stories and their worldviews. Where head-on attack would certainly fail, the parable hides the wisdom of the serpent behind the innocence of the dove, gaining entrance and favour which can then be used to change assumptions which the hearer would otherwise keep hidden away for safety. [ . . . ] Tell someone to do something, and you change their life-for a day; tell someone a story and you change their life. (Wright 1993, p. 40)

Yet, we are almost completely oblivious and immune to this subversive message if there is no point of intersection between our complex of personal stories and the public narrative of the liturgy. Our existing tacit knowledge or matrix of stories prevents us from even seeing the obvious symbol system of the kingdom that pervades the liturgy. For any new story to be subversive, it must come "close enough to the story already believed by the hearer for a spark to jump between them," and when it does, "nothing will ever be quite the same again" (ibid.).

Much of what liturgy needs to address lies beneath the surface in the deeply embedded implicit stories and tacit knowledge that people hold. These deeper stories may be precisely the source of the filters that prevent us from seeing in liturgy the obvious narrative and symbol set of the kingdom of God, yet they may not easily be addressed with explicit teaching. Drawing directly on the critical realism and related ideas of Michael Polanyi, Susan Wood calls the kind of knowledge that liturgy gives us access to participatory knowledge: "we acquire this knowledge by entering into the symbolic time and space of liturgical action. Within the liturgy we enter a formative environment that shapes our 
vision, our relationships, and our knowing" (Wood 2001, pp. 95-96). She explains that this form of knowledge is less rational, and more kinaesthetic, incarnate and embodied. Great emphasis must therefore be placed on participation in liturgy - not strictly speaking, on a rational level, but on the rituals, movement and embodied action by which we dwell within the liturgy. This is what James Smith also emphasises in his works on worship: repeated bodily practices, whether they be the liturgy or our secular rituals, create narrative spaces which shape our imagination, desires and character far more than we are consciously aware (Smith 2013). For Smith, so important is ritual action that even the imagination becomes a bodily form of intelligence (or praktognosia) that surpasses conscious reflection, and the mind seems only to be involved in organising thoughts after the real work is done. A balanced view of worship should see the liturgy as a place of dialogue between body and mind, of embodied imagination and values repatterned by ritual practice, and of conscious theological reflection on the participative, tacit knowledge perceived within the in-dwelt whole.

The narrative of the kingdom of God as inaugurated in the paschal mystery is precisely that whole within which we dwell in liturgy. To function properly as a narrative that shapes the participants in liturgy, it is therefore essential that the story of God's kingdom be fully proclaimed within worship. In liturgical proclamation and ritual enactment, the texts of the scriptures move from being literary narratives to being the typological interpretation of the events of salvation present in the life of the eucharistic community; they recount the transformation taking place within it, and the community assumes the story as their own. In this way, the narrative content of liturgy begins to work as an interpretive lens for our life, and it becomes what Polanyi describes as an interiorised faculty of tacit knowledge, much like the knowledge of a language or a tool, bestowing meaning on the world. Wright himself specifically says that the proclamation of the scriptures in liturgy is not primarily about teaching or "to impart information," but to "acclaim and celebrate God's mighty acts" (Wright 2017). He underscores the dynamic sacramental and prophetic role of the scriptures in worship, and laments that the whole narrative is seldom told, that many congregations are not even aware of the story of the kingdom. The story is "so explosive," he believes, that "the church in many generations has found it too much to take and so has watered it down, cut it up into little pieces, turned it into small-scale lessons rather than allowing its full impact to be felt" (Wright 2012, p. 276). Renewal of the liturgy as an event in which we can be shaped by the proclamation of the word and in which it becomes a tacit interpretive lens for our lives depends necessarily on the renewal of the lectionary, an initiative frequently raised as an issue needing urgent attention within Orthodox liturgical celebration. Wright makes a number of proposals that may be of use to Orthodox Christians, including reading longer sections to provide narrative context to lections, providing space within liturgy for continual reading (including of whole books, more often than just during Orthodox holy week), and interspersing reading with prayer, for instance praying "Our Father" after each chapter or section of a gospel (ibid. pp. 274-75). He also suggests that homilists take care to allow shorter readings within liturgy to become "windows on the larger narrative." In this way, he says, the scriptures may "provide fuel for the sacrificial flame which burns in our hearts, to bring us into the true Temple; to point ahead to God's new world and, by anticipating that new world in the present, actually to contribute by the Spirit to its effective realization" (Wright 2017).

\section{Conclusions}

The liturgical theologian Gordon Lathrop once said that the point of Christian worship is "to say the truth about God." Both John Zizioulas and NT Wright have allocated a considerable amount of their writing to arguing that this truth about God, for many reasons, has not been fully told. Over many centuries, the core scriptural narrative of the kingdom of God has been obscured or altogether lost, and the central Christian hope for the new world in which heaven and earth are for ever united has been transformed into a neo-gnostic expectation of private spiritual escape. 
The approach taken in this paper may be best conceived as a form of Venn diagram, exploring the issues of common concern between Zizioulas and Wright, intentionally seeking to read them both charitably and selectively in light of each other's work and to construct a dialogue between them, rather than subjecting them to a more thoroughgoing or harsher critical evaluation. As is the case for most prophetic voices, such critiques abound, and further comparative studies of our authors may well shed useful light on what their critics have written about them.

It is also worth remembering that, beyond this overlapping interest in the eclipse of the kingdom narrative, Zizioulas and Wright operate in very different theological spheres. As one of Orthodox Christianity's leading and most influential theologians, Zizioulas is known in the west primarily for his landmark work, Being as Communion: Studies in Personhood and the Church, as close to a work of philosophical or systematic theology as one can find in contemporary Orthodox theology, and one far less immediately grounded in either liturgical renewal or scriptural narrative, which is why it has not been focused on in this paper. A future paper could show, nevertheless, how this most well known of Zizioulas' works does still emerge from and reflect this core concern for the recovery of an underlying narrative of the age to come.

For his part, and though as a New Testament scholar he has naturally focused his attention on addressing the forgotten story of the kingdom within biblical studies, Wright is as explicitly committed as Zizioulas to a renewal of worship to express fully the story of the kingdom. They are, after all, both bishops as well as scholars. Both want a full recovery of the eschatological vision of the early church, and the restitution of a kingdom-oriented worship that conveys the world-upending message of the kingdom and shapes believers to participate now in the life of the age to come. Where Zizioulas tends towards a more systematic treatment of their shared concern and calls Orthodox Christians to recover the eschatological identity already embedded within the Divine Liturgy, Wright complements him with a profound treatment of the story of the kingdom as proclaimed through the life-giving words of the sacred scriptures. Wright's critical-realist epistemology completes the picture by pointing us towards the practical measures we can take to ensure that this story transforms us within the liturgy of the kingdom.

We inhabit a world of formative influences, in which a lifetime of individualistic consumerism, let alone a drift back into Platonic or gnostic variants of Christian faith, leaves its mark on our imagination and bends us away from God and his kingdom. The Christian answer to this challenge is simply to hear and live a story: "It is a love story-God's love story, operating through Jesus and then, by the Spirit, through Jesus's followers. This is the building of the church against which the powers of hell, and for that matter deconstruction, cannot prevail" (Wright 2012, p. 241). On the centrality and formative power of the narrative of God's kingdom, Wright and Zizioulas are firmly agreed, though in their prophetic articulation of this, each has faced some measure of controversy and opposition in their respective traditions, a fuller treatment of which lies outside the scope of this present paper. We may nevertheless hope that, by bringing these two scholars into constructive dialogue, their collective invitation to a full, participatory knowledge of this story of the kingdom of God may be heard by all Christians.

Funding: This research received no external funding.

Conflicts of Interest: The author declares no conflict of interest.

\section{References}

Smith, James K. A. 2013. Imagining the Kingdom: How Worship Works. Grand Rapids: Baker Publishing.

Wood, Susan. 2001. Participatory Knowledge of God in the Liturgy. In Knowing the Triune God: The Work of the Spirit in the Practices of the Church. Grand Rapids: W.B. Eerdmans, pp. 95-118.

Wright, N. T. 1993. The New Testament and the People of God: Christian Origins and the Question of God. Minneapolis: Fortress Press, vol. 1. Wright, N. T. 1997. For All God's Worth: True Worship and the Calling of the Church. Grand Rapids: Eerdmans.

Wright, N. T. 2002. Freedom and Framework, Spirit and Truth: Recovering Biblical Worship. Studia Liturgica 32: 176-95. [CrossRef] Wright, N. T. 2012. How God Became King: The Forgotten Story of the Gospels. San Francisco: HarperOne. 
Wright, N. T. 2016. The Day the Revolution Began: Reconsidering the Meaning of Jesus's Crucifixion. San Francisco: HarperOne.

Wright, N. T. 2017. Sign and Means of New Creation: Public Worship and the Creative Reading of Scripture. In Symposium on Worship. Grand Rapids: Calvin College, Available online: http://ntwrightpage.com/2017/01/30/sign-and-means-of-new-creationpublic-worship-and-the-creative-reading-of-scripture (accessed on 15 January 2021).

Zizioulas, John. 2008. Lectures in Christian Dogmatics. Edited by Douglas Knight. New York: T \& T Clark.

Zizioulas, John. 2010. The One and the Many: Studies on God, Man, the Church, and the World Today. Edited by Gregory Edwards. Alhambra: Sebastian Press.

Zizioulas, John. 2011. The Eucharistic Communion and the World. New York: T \& T Clark. 